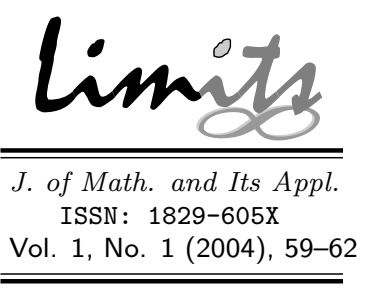

\title{
Penerapan Matriks Transisi Pada Perubahan Fungsi Interpolasi Elemen Hingga
}

\author{
Kamiran \\ Jurusan Matematika \\ Institut Teknologi Sepuluh Nopember, Surabaya
}

\begin{abstract}
Abstrak
Sebelum membentuk matriks kekakuan $[K]\{\alpha\}=\{f\}$ pada metoda elemen hingga, biasanya didahului dengan memilih fungsi interpolasi sebagai pendekatan untuk menyelesaikan setiap persoalan syarat batas. Dan dalam hal ini akan sangat menarik untuk mengkaji adanya perubahan fungsi interpolasi yang dapat dikaitkan dengan perubahan basis sehingga berkaitan dengan matriks transisi ,seperti pada teori aljabar linier.
\end{abstract}

Kata kunci: matriks kekakuan, fungsi interpolasi, metoda elemen hingga, matriks transisi

\section{Pendahuluan}

Penyelesaian pendekatan dengan metoda elemen hingga pada persoalan syarat batas untuk bidang rekayasa, seperti; mekanika fluida, distribusi temperatur, serta elastisitas-benda padat dan lain-lain, yang mana biasanya diawali dengan pemilihan fungsi inteinterpolasi. Dan berbagai bentuk fungsi interpolasi ini dapat dilihat pada Segerlin [1]. Selanjutnya disini akan dikaji adanya keterkaitan dua fungsi interpolasi yang akan dipakai sebagai penyelesaian pendekatan metoda elemen hingga pada persoalan elastisitas berdimensi satu, sedemikian hingga terbentuk matriks kekakuan $[K]\{\alpha\}=\{f\}$ yang berarti dari fungsi interpolasi pertama $U^{(1)}$ akan didapat matriks kekakuan $\left[K^{(1)}\right]\left\{\alpha^{(1)}\right\}=\left\{f^{(1)}\right\}$ dan dari fungsi interpolasi kedua $U^{(2)}$ akan didapat matriks kekauan $\left[K^{(2)}\right]\left\{\alpha^{(2)}\right\}=\left\{f^{(2)}\right\}$. Kemudian akan dicari keterkaitan antara $\left[K^{(1)}\right]$, $\left\{f^{(1)}\right\}$ dengan $\left[K^{(2)}\right],\left\{f^{(2)}\right\}$.

\section{Permasalahan}

Pandang suatu batang pejal yang mengalami gaya tarik $p$, seperti pada gambar berikut:

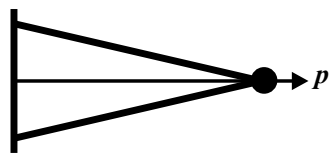

Gambar 1: Batang mengalami gaya tarik

Maka fungsional yang berlaku untuk persoalan seperti diatas [2], adalah:

$$
\int_{0}^{L}\left(\delta \frac{d u}{d x}\right) E A\left(\delta \frac{d u}{d x}\right)=2 \int_{0}^{L} A P U d x
$$

dimana $A$ adalah luas penampang lintang batang dan $E$ adalah modulus elastisitas Young. Selanjutnya bila digunakan fungsi interpolasi berbentuk

$$
U=[N]\{a\}
$$

dan

$$
\frac{d U}{d x}=\frac{d[N]}{d x}\{a\}=[B]\{a\}
$$

serta dengan mengasumsikan

$$
\delta \frac{d U}{d x}=[B]^{t}
$$


maka (1) menjadi

$$
\int_{0}^{L}[B]^{t} E A[B] d x\{a\}=2 \int_{0}^{L} A P[N]^{t} d x
$$

persamaan diatas disebut sebagai matriks kekakuan dan dapat ditulis sebagai

$$
[K]\{a\}=\{f\}
$$

dimana $\{f\}=\int_{0}^{L} 2 A P[N]^{t} d x$. Selanjutnya yang menjadi permasalahannya adalah apabila digunakan dua fungsi interpolasi yakni

$$
\begin{aligned}
& U^{(1)}=a_{1} x+a_{2} x^{2} \\
& U^{(2)}=b_{1} x+b_{2}\left(x-x^{2}\right)
\end{aligned}
$$

Untuk perhitungan pada Persamaan (6) maka akan dicari keterkaitan dari dua bentuk matriks kekakuan yang dihasilkan oleh penggunaan dua fungsi interpolasi tersebut, dan untuk mendapatkan gambaran yang jelas dari persoalan diatas maka dapat diambil contoh kasus sederhana dari aljabar linier elementer [3], sebagai berikut: dari Persamaan (6), yaitu: $[K]\{a\}=\{f\}$ dilakukan perubahan $\{a\}$ yang berkaitan dengan matriks transisi $[T]$ sehingga $\{a\}=[T]\{\widehat{a}\}$ dan $\{f\}=[T]\{\widehat{f}\}$ dengan demikian maka $[K]\{a\}=\{f\}$ menjadi $[K][T]\{\widehat{a}\}=[T]\{\widehat{f}\}$ atau $[T]^{-1}[K][T]\{\widehat{a}\}=$ $\{\widehat{f}\}$ untuk $[\widehat{K}]\{\widehat{a}\}=\{\widehat{f}\}$ maka didapat $[\widehat{K}]=$ $[T]^{-1}[K][T]$.

\section{Contoh: Misal}

$$
[K]=\left[\begin{array}{cc}
1 & 1 \\
2 & -1
\end{array}\right],\{a\}=\left\{\begin{array}{l}
1 \\
1
\end{array}\right\},\{f\}=\left\{\begin{array}{l}
2 \\
1
\end{array}\right\}
$$

dan diandaikan matriks transisinya adalah

$$
[T]=\left[\begin{array}{ll}
1 & 2 \\
1 & 3
\end{array}\right] \quad \text { maka }[T]^{-1}=\left[\begin{array}{cc}
3 & -2 \\
-1 & 1
\end{array}\right]
$$

sehingga diperoleh

$$
\begin{gathered}
{[\widehat{K}]=[T]^{-1}[K][T]=\left[\begin{array}{cc}
4 & 3 \\
-1 & -4
\end{array}\right]} \\
\{\widehat{a}\}=[T]^{-1}\{a\}=\left\{\begin{array}{l}
1 \\
0
\end{array}\right\}
\end{gathered}
$$

dan

$$
\{\widehat{f}\}=[T]^{-1}\{f\}=\left\{\begin{array}{c}
4 \\
-1
\end{array}\right\}
$$

\section{Pembahasan}

Masing-masing fungsi interpolasi pada Persamaan (7) dan (8) akan digunakan pada Persamaan (6) dan dalam perhitungan ini juga dimisalkan luas permukaan batang diujung kanan adalah dua kali luas permukaan batang diujung kirinya, sehingga persamaan luas penampangnya adalah:

$$
A=\left(1+\frac{x}{L}\right) A_{0}, \quad 0 \leq x \leq L
$$

Sehingga untuk Persamaan (7)

$$
U^{(1)}=a_{1} x+a_{2} x^{2}=\left[\begin{array}{ll}
x & x^{2}
\end{array}\right]\left\{\begin{array}{l}
a_{1} \\
a_{2}
\end{array}\right\}
$$

Seperti pada Persamaan (2), didapat

$$
\left[N^{(1)}\right]=\left[\begin{array}{ll}
x & x^{2}
\end{array}\right]
$$

Sehingga untuk Persamaan (7)

$$
\left[B^{(1)}\right]=\left[\begin{array}{ll}
1 & 2 x
\end{array}\right] \text {. }
$$

Dengan demikian komponen Persamaan (6) dapat dihitung, sebagai berikut

$$
\begin{aligned}
{\left[K^{(1)}\right] } & =\int_{0}^{L}\left[B^{(1)}\right]^{t} E A\left[B^{(1)}\right] d x \\
& =E A_{0} \int_{0}^{L}\left(1+\frac{x}{L}\right)\left[\begin{array}{ll}
1 & 2 x \\
1 & 2 x
\end{array}\right] d x \\
& =E A_{0}\left[\begin{array}{cc}
\frac{3 L}{2} & \frac{5 L^{2}}{3} \\
\frac{5 L^{2}}{3} & \frac{7 L^{2}}{3}
\end{array}\right]
\end{aligned}
$$

$$
\begin{aligned}
\left\{f^{(1)}\right\} & =\int_{0}^{L} 2 A P\left[N^{(1)}\right]^{t} d x \\
& =2 A_{0} P \int_{0}^{L}\left(1+\frac{x}{L}\right)\left[\begin{array}{c}
x \\
x^{2}
\end{array}\right] d x \\
& =2 A_{0} P\left\{\begin{array}{c}
\frac{5 L^{2}}{6} \\
\frac{7 L^{3}}{12}
\end{array}\right\}
\end{aligned}
$$

Sehingga menghasilkan matriks kekakuan yang pertama sebagai berikut

$$
\left[K^{(1)}\right]\{a\}=\left\{f^{(1)}\right\}
$$

dan penyelesaiannya adalah sebagai berikut

$$
\{a\}=\frac{P L}{E}\left\{\begin{array}{c}
\frac{105}{78} \\
\frac{-37}{52 L}
\end{array}\right\}
$$


sedangkan untuk Persamaan (8)

$$
U^{(2)}=b_{1} x+b_{2}\left(x-x^{2}\right)=\left[x\left(x-x^{2}\right)\right]\left\{\begin{array}{l}
b_{1} \\
b_{2}
\end{array}\right\}
$$

Didapat

$$
\begin{aligned}
& {\left[N^{(2)}\right]=\left[x\left(x-x^{2}\right)\right]} \\
& {\left[B^{(1)}\right]=[1(1-2 x)]}
\end{aligned}
$$

Maka komponen Persamaan (6) dapat dihitung, sebagai berikut

$$
\begin{aligned}
& {\left[K^{(2)}\right]=\int_{0}^{L}\left[B^{(2)}\right]^{t} E A\left[B^{(2)}\right] d x} \\
& =E A_{0} \int_{0}^{L}\left(1+\frac{x}{L}\right)\left[\begin{array}{ll}
1 & (1-2 x) \\
1 & (1-2 x)
\end{array}\right] d x \\
& =E A_{0}\left\{\begin{array}{cc}
\frac{3 L}{2} & \frac{3 L}{2}-\frac{5 L^{2}}{3} \\
\frac{3 L}{2}-\frac{5 L^{2}}{3} & \frac{3 L}{2}-\frac{10 L^{2}}{3}+\frac{7 L^{3}}{3}
\end{array}\right\} d x \\
& \left\{f^{(2)}\right\}=\int_{0}^{L} 2 A P\left[N^{(2)}\right]^{t} d x \\
& =2 A_{0} P \int_{0}^{L}\left(1+\frac{x}{L}\right)\left\{\begin{array}{c}
x \\
x-x^{2}
\end{array}\right\} d x \\
& =2 A_{0} P \int_{0}^{L}\left\{\begin{array}{c}
\frac{5 L^{2}}{6} \\
\frac{5 L^{2}}{6}-\frac{7 L^{3}}{12}
\end{array}\right\} d x
\end{aligned}
$$

sehingga diperoleh matriks kekakuan yang kedua, sebagai berikut

$$
\left[K^{(2)}\right]\{b\}=\left\{f^{(2)}\right\}
$$

dan penyelesaiannya, adalah

$$
\{b\}=\frac{P L}{E}\left\{\begin{array}{c}
\frac{105}{78}-\frac{37}{52 L} \\
\frac{37}{52 L}
\end{array}\right\}
$$

Selanjutnya keterkaitan kedua matriks kekakuan tersebut karena adanya perubahan vektor pada Persamaan (9) dan (10) menjadi Persamaan (12) dan (13) sehingga didapat persamaan

$$
\left[N^{(1)}\right]^{t}=[T]\left[N^{(2)}\right]^{t}
$$

atau

$$
\begin{aligned}
& \left\{\begin{array}{c}
1 \\
2 x
\end{array}\right\}=[T]\left\{\begin{array}{c}
1 \\
1-2 x
\end{array}\right\} \\
& {\left[B^{(1)}\right]^{t}=[T]\left[B^{(2)}\right]^{t}}
\end{aligned}
$$

atau

$$
\left\{\begin{array}{c}
1 \\
x^{2}
\end{array}\right\}=[T]\left\{\begin{array}{c}
1 \\
x-x^{2}
\end{array}\right\}
$$

sehingga dengan menghasilkan matriks transisi

$$
[T]=\left[\begin{array}{cc}
1 & 0 \\
1 & -1
\end{array}\right]
$$

Selanjutnya pada matriks kekakuan yang pertama atau Persamaan (11), yaitu

$$
\left[K^{(1)}\right]\{a\}=\left\{f^{(1)}\right\}
$$

atau

$\int_{0}^{L}\left[B^{(1)}\right]^{t} E A\left[B^{(1)}\right] d x\{a\}=2 \int_{0}^{L} A P\left[N^{(1)}\right]^{t} d x$ substitusikan Persamaan (13) dan (14) sehingga didapat

$$
\begin{gathered}
\int_{0}^{L}[T]\left[B^{(2)}\right]^{t} A\left[B^{(2)}\right] d x[T]^{t}\{a\} \\
=2 \int_{0}^{L}[T] A P\left[N^{(2)}\right]^{t} d x .
\end{gathered}
$$

Jika pada kedua ruas pada persamaan diatas dikalikan dengan $[T]^{-1}$ maka diperoleh

$$
\begin{array}{r}
\int_{0}^{L}\left[B^{(2)}\right]^{t} E A\left[B^{(2)}\right] d x[T]^{t}\{a\} \\
=2 \int_{0}^{L} A P\left[N^{(2)}\right]^{t} d x .
\end{array}
$$

Bentuk persamaan terakhir ini tampak identik dengan Persamaan (14) atau bentuk persamaan matrik kekakuan, sehingga diperoleh kenyataan bahwa

$$
\{b\}=[T]^{t}\{a\}
$$

Dengan demikian untuk matriks transisi

$$
[T]=\left[\begin{array}{cc}
1 & 0 \\
0 & -1
\end{array}\right] \quad \text { dan } \quad\{a\}=\frac{P L}{E}\left\{\begin{array}{c}
\frac{105}{78} \\
\frac{-37}{52 L}
\end{array}\right\}
$$


maka

$$
\begin{aligned}
\{b\} & =[T]^{t}\{a\} \\
& =\left[\begin{array}{cc}
1 & 1 \\
0 & -1
\end{array}\right] \frac{P L}{E}\left\{\begin{array}{c}
\frac{105}{78} \\
\frac{-37}{52 L}
\end{array}\right\} \\
& =\frac{P L}{E}\left\{\begin{array}{c}
\frac{105}{78}-\frac{37}{52 L} \\
\frac{-37}{52 L}
\end{array}\right\}
\end{aligned}
$$

\section{Kesimpulan}

Dari pembahasan diatas dapat disimpulkan bahwa apabila dua fungsi interpolasi yang berbeda pada suatu persoalan elemen hingga maka penyelesaiannya akan berkait erat dengan matriks transisi yang bersesuaian dengan perubahan vektor $[N]$ dan $[B]$.

\section{Daftar Pustaka}

[1] Segerlin, L.J., Applied Finite Element Analysis, John Wiley \& Sons, Inc., New York, 1984.

[2] Bathe, K.J., Finite Element Procedures in Engineering Analysis, Prentice-Hall, Inc., New Jersey, 1982

[3] Howard Anton \& Chris Rorrer, Elementary Linear Algebra, John Wiley \& Sons, Inc., New York, 1991 